Egyptian Journal of Rabbit Science, 25(2): 197 - 209(2015)

\title{
IMPACT OF SOY-LECITHIN BASED EXTENDER ON QUALITY AND FERTILITY OF PRESERVED RABBIT SEMEN
}

\author{
F. E. El-Azzazi and A. M. Hanafy \\ Department of Animal Production, Faculty of Agriculture, Suez Canal \\ University, Ismailia, Egypt.
}

The current study aimed to evaluate the impact of soy lecithin, instead of egg yolk, in extenders on quality and fertility of rabbit semen preserved at $4^{\circ} \mathrm{C}$. Six mature New Zealand White rabbits were used for semen collection. Two different concentrations of soybean lecithin; L1 (1\% lecithin and $10 \%$ egg yolk) and L2 (only 2\% lecithin) were compared with LO (free lecithin Tris-Yolk extender) as a control. Good quality ejaculates (initial motility $\geq 70 \%$ ) were diluted to four fold with specified extender and preserved for three days at $4^{\circ} \mathrm{C}$. Progressive motility and viability were examined in pooled and diluted semen samples. In addition, fertility test was carried out on 98 multiparous rabbit does using one day preserved $\left(4^{\circ} \mathrm{C}\right)$ extended semen.

Results showed that both lecithin-containing extenders slightly improved rabbit sperm motility. The decline rate in sperm motility by progress of preservation time was decreased in lecithin-based extenders compared to egg-yolk extenders. After one day of storage, the best progressive motility was observed in L1, but with nonsignificant differences. Both $48 \mathrm{~h}$ and $72 \mathrm{~h}$ of preservation at $4^{\circ} \mathrm{C}$ showed better results $(P<0.05)$ which were obtained for $L 1$ and $L 2$ as compared to LO. Sperm viability did not differ significantly all over the total periods of cold storage. There were no significant differences in pregnancy rates for artificially inseminated does with lecithin supplemented extenders (L1: $61.8 \%$ and L2: 60.0\%) compared to control (L0: $58.8 \%$ ).

Conclusively, soybean lecithin could be included in rabbit semen extenders as a non-animal origin instead of egg yolk. It maintained motility, viability values of chilled-stored spermatozoa and preserved their fertilizing capacity.

Keywords: Rabbits, semen preservation, soybean lecithin, fertility, biological risk. 
Chilled storage of buck semen is now a common practice in commercial rabbit breeding due to the highly variable and unsatisfactory fertility rates achieved after cryopreservation (Mocé and Vicente 2009). Lopez and Alvarino (1998) recorded acceptable fertility when they use diluted, cooled buck semen stored for up to 4 days. Although quality and viability of the sperm gradually deteriorates during liquid storage, addition of a suitable extender prevents cell membrane against damages during cooling (Aires et al., 2003). As in most species, semen extenders used in preserving rabbit semen usually contains an animal product such as egg yolk and milk. Extenders based on egg yolk provide comparable results but are more complicated to process and generally do not result in enhanced semen quality or fertility (Gil et al., 2003 and Bencharif et al., 2008).

A sterile soybean extract is a new generation of semen diluents often used instead of egg yolk or milk (Anel et al., 2006; 2008). Soy lecithin-based diluents were introduced by the commercial AI companies at the beginning of year 2000 (Gil et al., 2000 and Thun et al., 2002). Many researchers compared such an extender with a conventional egg yolk extender and found that the latter generally gave acceptable preserve effect and better fertility, but that results varied between breeds (van Wagtendonk-de Leeuw et al., 2000 and Kmenta et al., 2011). However, Aires et al. (2003) reported clear benefits from using a soy-lecithin extender as compared to an egg yolk containing extender. Soy lecithin may thus be a good alternative, if there is a concern regarding microbial contamination that may negatively affect semen quality during low temperature storage, and impair fertilizing capacity of spermatozoa (Aurich and Spergser, 2007).

The current study was carried out to investigate the potential benefits of replacing the non-animal origin, soy lecithin, substance with egg yolk in Tris-based extender for the liquid storage of rabbit semen at $4^{\circ} \mathrm{C}$.

\section{MATERIALS AND METHODS}

\section{Animals and semen collection}

The current study was conducted in the Experimental Animal Production Farm, Faculty of Agriculture, Suez Canal University, Ismailia, Egypt. Six mature New Zealand White rabbit bucks $(4.10 \pm 0.4 \mathrm{~kg}$ body weight and about one year age) were used for semen collection. Bucks were housed in flat-deck cages with semi-opened system. Animals were fed a commercial standard diet that contains $20 \%$ total protein and $2600 \mathrm{~K} \mathrm{Cal}$ digestible energy. Drinking water was automatically offered freely.

Two ejaculates per male were collected twice a week by using an artificial vagina. Only ejaculates presenting white, opalescent appearance and 
initial motility more than $70 \%$ were utilized. Good quality ejaculates were mixed together and treated as one pooled semen sample. The microscopic attributes of ejaculates were reported in Table 1. After assessment of semen quality, each pool was splitted into three portions and each was fourfold extended $(\mathrm{v} / \mathrm{v})$ with one of the below extenders at room temperature.

\section{Preparation of semen extenders}

Basic extender was composed of 3.028g Tris, 1.675g Citric Acid and $1.250 \mathrm{~g}$ fructose. After dissolving all of these ingredients in $100 \mathrm{~mL}$ distilled water, the antibiotics were added (500 IU Penicillin and $500 \mu \mathrm{g}$ Streptomycin $/ \mathrm{mL}$ ) to the basic extender. The basic extender was splitted into three parts, each was supplemented with egg yolk or soybean lecithin (LE030A- Bio Basic) as follow L0 (zero lecithin and 15\% egg yolk), L1 (1\% lecithin and $10 \%$ egg yolk) and L2 (2\% lecithin and zero egg yolk). Then, $\mathrm{pH}$ was adjusted to be seven using ADWA pH meter (AD1040, Romania).

\section{Sperm motility and viability}

Sperm motility was assessed by visual estimation using a phase contrast microscope (Olympus, Japan) equipped with warmed stage at the nearest 5\% as described by Roca et al., (2000). The microscope was conducted to video screened Scalar USB Camera (USB Shot, M3, Japan). A drop of $10 \mu \mathrm{L}$ of semen was delivered onto a clean glass slide and covered with a cover slip. Percentages of spermatozoal progressive motility were estimated at $600 \mathrm{X}$ magnification. The sperm viability was measured using the Live/Dead Sperm Viability Kit containing Eosin-Nigrosine-based stains using phase contrast microscope. Evaluation of pooled then diluted semen samples was performed immediately after dilution (Initial) and periodically after one, 24 and 48 hours of cold storage at $4^{\circ} \mathrm{C}$. Progressive motility examination was estimated at extended time $(72 \mathrm{~h})$ for all samples as a suitable indicator for sperm prolongevity and activity under prolonged stress of chilling conditions.

\section{Fertility test}

During the last week of experiment, fertility test was done to compare the three types of extenders. Ninety-eight multiparous rabbit does were used, their age averaged one year and their weight averaged $3.25-3.50 \mathrm{~kg}$. At the time of insemination, rabbit does were induced for ovulation by administration of $20 \mu \mathrm{g}$ of $\mathrm{GnRH}$ analogue $(0.2 \mathrm{ml}$ intramuscularly injection of Buserlin, Intravet, Holand) according to Morrell (1995). Each female rabbit was inseminated with a dose of $50 \times 10^{6}$ motile sperm as described by Quintela et al. (2004). For AI procedure, female rabbits were placed carefully on a stable bench and inseminating pipettes, with a $5 \mathrm{~mm}$ diameter of glass tubes, were inserted $10-15 \mathrm{~cm}$ into vagina to ensure appropriate delivery of sperm 
Table (1). Means \pm SE of initial characteristics of pre-treated semen samples collected from NZW rabbit bucks.

\begin{tabular}{lc}
\hline \multicolumn{1}{c}{ Parameters } & Mean \pm SE \\
\hline Ejaculate Volume (ml) & $0.66 \pm 0.15$ \\
Concentration $\left(X 10^{6} / \mathrm{ml}\right)$ & $429.14 \pm 13.54$ \\
Progressive Motility $(\%)$ & $76.84 \pm 0.33$ \\
Sperm Viability $(\%)$ & $90.92 \pm 0.41$ \\
\hline
\end{tabular}

to female rabbits (Morrell, 1995 and Houdebine and Fan, 2009). Pregnancy diagnoses were confirmed at twelve days of AI by abdominal palpation. Conception rate was calculated as a percentage of the number of pregnant females from all inseminated females.

\section{Bacterial culture}

At the same time of insemination, $24 \mathrm{~h}$ of storage, $1.5 \mathrm{~mL}$ aliquots semen samples were immediately transported to Diagnostic Laboratory for calculating the total bacterial charge. Each extended sample was surface plated on blood agar and MacConkey agar by using standard loops (0.001 $\mathrm{ml}$ ) of specimen. The blood agar and MacConkey agar plates were incubated in aerobic conditions at $37^{\circ} \mathrm{C}$ for $24 \mathrm{~h}$. Aerobic cultures were considered positive when one observed colony, equivalent to 1000 organisms $/ \mathrm{mL}$, were noted.

\section{Statistical analysis}

Data of semen motility and viability were analyzed using the General Linear Model (GLM) procedure of SAS (SAS, 2004). Differences among treatments and sampling were performed (Duncan, 1955). Data on conception rates were statistically analyzed using Pearson Chi-square test. All differences were considered statistically significant at $(P \leq 0.05)$.

\section{RESULTS AND DISCUSSION}

The average of initial semen characteristics, as shown in Table (1), for semen ejaculate volume $(\mathrm{ml})$, sperm cell concentration and parentages of progressive motility and viability were $0.66,429.14 \times 10^{6} \mathrm{sperm} / \mathrm{ml}, 76.84$ and 90.92 , respectively. All obtained values of pooled samples were in normal ranges of rabbit semen characteristics.

Sperm motilities determined immediately after semen dilution (Initial) and after preservation until $24 \mathrm{~h}$ of storage at $4^{\circ} \mathrm{C}$ showed no significant differences between the three extenders (Table 2 and Figures $1 \& 2$ ). 
Table 2. Mean $( \pm \mathrm{SE})$ percentages of sperm motility and viability as affected by different lecithin supplementation to rabbit semen extender preserved at $4^{\circ} \mathrm{C}$ for $72 \mathrm{~h}$.

\begin{tabular}{|c|c|c|c|c|c|c|c|c|c|}
\hline \multirow{2}{*}{$\begin{array}{c}\text { Lecithin } \\
\text { level }\end{array}$} & \multicolumn{5}{|c|}{ Sperm Motility \% } & \multicolumn{4}{|c|}{ Sperm Viability (\%) } \\
\hline & Initial $^{*}$ & $1 \mathrm{~h}$ & $24 \mathrm{~h}$ & $48 \mathrm{~h}$ & $72 \mathrm{~h}$ & Initial & $1 \mathrm{~h}$ & $24 \mathrm{~h}$ & $48 \mathrm{~h}$ \\
\hline Lo & $\begin{array}{c}76.42 \pm \\
0.31 \\
\end{array}$ & $\begin{array}{l}73.92 \\
\pm 0.83 \\
\end{array}$ & $\begin{array}{r}70.08 \\
\pm 1.13 \\
\end{array}$ & $\begin{array}{l}58.58^{b} \\
\pm 2.23 \\
\end{array}$ & $\begin{array}{l}44.44^{\mathrm{b}} \\
\pm 3.88 \\
\end{array}$ & $\begin{array}{l}90.77 \\
\pm 0.37 \\
\end{array}$ & $\begin{array}{l}87.11 \\
\pm 0.51 \\
\end{array}$ & $\begin{array}{l}84.44 \\
\pm 0.71 \\
\end{array}$ & $\begin{array}{r}76.28 \\
\pm 0.69 \\
\end{array}$ \\
\hline $\mathbf{L 1}$ & $\begin{array}{c}76.58 \pm \\
0.35 \\
\end{array}$ & $\begin{array}{l}74.08 \\
\pm 0.84 \\
\end{array}$ & $\begin{array}{l}71.92 \\
\pm 1.14 \\
\end{array}$ & $\begin{array}{l}62.83^{\mathrm{a}} \\
\pm 2.05 \\
\end{array}$ & $\begin{array}{l}46.25^{\mathrm{a}} \\
\pm 3.73 \\
\end{array}$ & $\begin{array}{l}90.80 \\
\pm 0.39 \\
\end{array}$ & $\begin{array}{l}86.60 \\
\pm 0.53 \\
\end{array}$ & $\begin{array}{r}83.93 \\
\pm 0.73 \\
\end{array}$ & $\begin{array}{r}76.69 \\
\pm 0.74 \\
\end{array}$ \\
\hline L2 & $\begin{array}{c}76.67 \pm \\
0.37\end{array}$ & $\begin{array}{l}73.58 \\
\pm 0.93\end{array}$ & $\begin{array}{l}70.50 \\
\pm 1.35\end{array}$ & $\begin{array}{l}63.28^{\mathrm{a}} \\
\pm 1.99\end{array}$ & $\begin{array}{l}46.25^{\mathrm{a}} \\
\pm 3.01\end{array}$ & $\begin{array}{l}90.88 \\
\pm 0.39\end{array}$ & $\begin{array}{l}86.34 \\
\pm 0.51\end{array}$ & $\begin{array}{l}84.80 \\
\pm 0.57\end{array}$ & $\begin{array}{l}77.05 \\
\pm 0.63\end{array}$ \\
\hline
\end{tabular}

$\mathrm{a}, \mathrm{b}, \ldots$ Means in the same column with different superscripts differ significantly $(P<0.05)$.

${ }^{(*)}$ Initial; evaluation soon after extension; 1, 24, 48 and $72 \mathrm{~h}$; refer to the times of semen evaluation under cooled storage.

At 48 and $72 \mathrm{~h}$ of cold storage, results demonstrated a significant $(\mathrm{P}<0.05)$ improvement in motility by partially (L1) or completely (L2) lecithin replacement instead of egg yolk extender and the best values of sperm motility were observed when extender contained $2.0 \%$ lecithin at $48 \mathrm{~h}(63.28 \%)$. At $24 \mathrm{~h}$ of cold storage, decline of sperm motility were nearly by the same ratios in the three extenders. Nevertheless, at $48 \mathrm{~h}$ of preservation, the decline was increased $(-11.5 \%)$ in free lecithin extender compared to L1 $(-9.09 \%)$ and L2 $(-7.22 \%)$ extenders. Sperm motility largely decreased after 3 days of preservation at $4{ }^{\circ} \mathrm{C}$ by the rate of $41.85 \%, 39.61 \%$ and $39.68 \%$ for $\mathrm{L} 0, \mathrm{~L} 1$ and L2, respectively.

Regarding the effect of different levels of soybean lecithin supplementation on the viable spermatozoa after preservation of rabbit semen at $4^{\circ} \mathrm{C}$, results revealed no significant differences were found among the effect of different extenders on sperm viability of rabbit semen throughout cold preservation at $4^{\circ} \mathrm{C}$ (Table 2). At $24 \mathrm{~h}$ of preservation, viability was decreased by the rate of $6.97,7.57$ and $6.69 \%$ for L0, L1 and L2, respectively. While high decreasing rates were observed at $48 \mathrm{~h}$ of cold storage (15.96, 15.54 and $15.22 \%$ for L0, L1 and L2, respectively). It could be noted that after $48 \mathrm{~h}$ of cold storage, livability was slightly maintained as influenced by the lecithin extenders compared to Egg-Yolk-based extender. In another words, extenders containing $1 \%$ or $2 \%$ lecithin concentration were more 


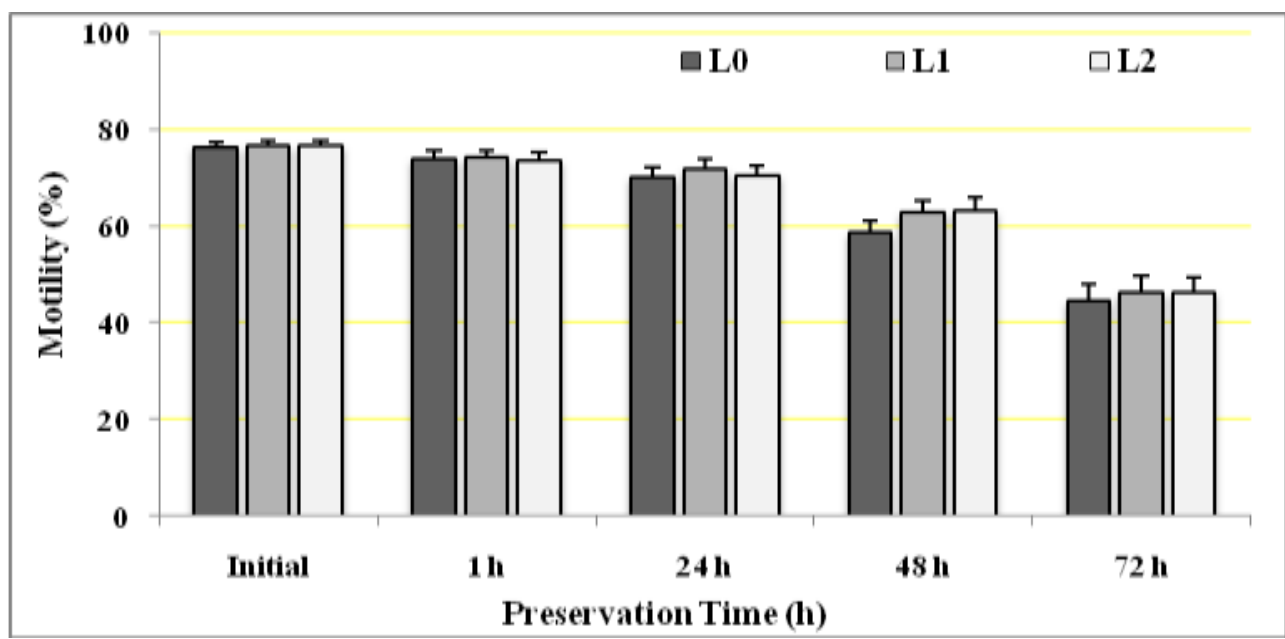

Figure 1. Effect of Lecithin supplementation to rabbit semen extender on sperm motility during preservation at $4^{\circ} \mathrm{C}$ for $72 \mathrm{~h}$.

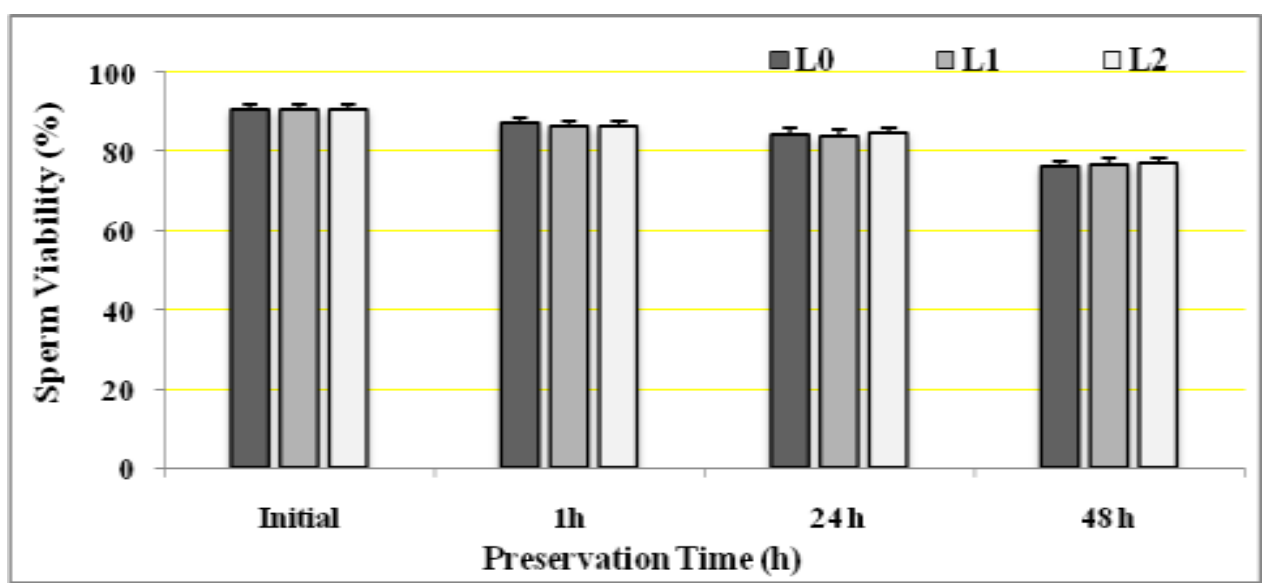

Figure 2. Percentages of sperm viability as affected by lecithin supplementation to rabbit semen extender after preservation at $4^{\circ} \mathrm{C}$.

appropriate in cold preservation of rabbit buck semen in comparison to a conventional egg yolk-based extender.

Several researchers (Kmenta et al., 2011 and Salmani et al., 2013, Phutikanit et al., 2011; Vidal et al., 2013,) in their studies on equine, canine, buffalo, goat and ram semen came to the same conclusion. In addition, Yotov (2015) found that using Tris-Fructose-Citric acid (TFC)-based extender containing $1.5 \%$ soybean lecithin provided the best motility, viability of chilled-store goat semen. On the other hand, soybean lecithin could be used as well and is equally capable as egg yolk for protection of bovine, ram, and stallion spermatozoa during freezing (Aires et al., 2003 and Ricker et al., 2006). Papa et al. (2010) found no difference in post-thaw motility and 
viability between the egg yolk and soybean lecithin treatment but the fertility was reduced for semen frozen in the soybean lecithin extender. The authors attributed that to irreversible binding of the phospholipid's lecithin to sperm membrane, which might interact with the capacitation process.

The current findings are in agreement also with Zhang et al., 2009, who reported that extenders based on soy lecithin, improves the kinematics characteristics of sperm cells compared to the extenders commonly used.

The decline of sperm motility, viability and consequently fertility during chilled storage can be attributed to the oxidative stress through excessive formation of reactive oxygen species (ROS), particularly hydrogen peroxide. Excessive ROS production can result in oxidative damage and impairment of sperm fertility (Bucak and Tekin, 2007 and Kim et al., 2011). Furthermore, Farstad (1996) mentioned that soy lecithin protects the sperm cells membrane by restoring the phospholipids lost during heat shock.

The present results revealed that, dramatically decreasing rates in sperm motility percentages were observed after $24 \mathrm{~h}$ of cold storage while the other estimate, sperm viability, seems to be higher in its values (Figures 1 and 2) at the same sampling time. The higher percentages of viability and notably differences with sperm motility at the same sampling time refer to the presence of high percentage of immotile-live spermatozoa.

Many ingredients of semen extenders may act as stabilizers for microorganisms at chilled or freezing temperatures. To avoid the spreading of infectious diseases, one must rely on using controlled and monitored ingredients and reagents that are guaranteed free of pathogens and/or mainly inhabited bacterial growth. Consequently, a defined extender containing soybean lecithin has been developed to prevent possible disease transmission by animal proteins (Pagl et al., 2006).

As presented in Figure (3), the three extenders showed positive bacterial numbers (colony forming units, cfu) in the samples results from $2.66 \times 10^{3} \mathrm{cfu} / \mathrm{mL}$ in $\mathrm{L} 0$ to $2 \times 10^{3} \mathrm{cfu} / \mathrm{mL}$ in $\mathrm{L} 1$, with an average total microbial count of $1 \times 10^{3} \mathrm{cfu} / \mathrm{mL}$ in L2. The obtained results are consistent with researches investigated that non-animal substitute of egg yolk in an extender results in improved bacteriological qualities which protect the sperm from toxins produced by bacteria in the semen (Gil et al., 2003 and Bencharif et al., 2008). Although antibiotics are added routinely to semen extenders to control the growth of contaminating bacteria, their use and efficacy has still been questioned (Aurich and Spergser, 2007). Corona and Cherchi (2009) reported that additions of antibiotics to the cryoprotective medium are not adequate to protect the frozen semen from microbial contamination. 


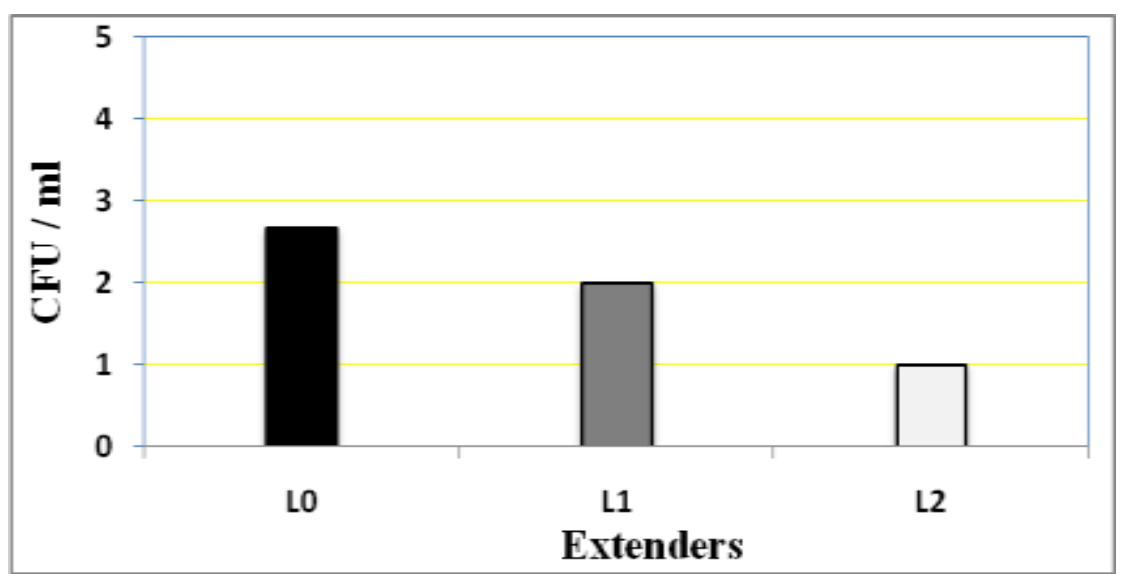

Figure 3. Bacterial count in three different lecithin levels performed with independent three semen samples.

Table (3) represents the pregnancy rates of multiparous rabbit does artificially inseminated with various extenders $(58.82,61.76$ and $60.00 \%$ for L0, L1 and L2, respectively). Differences in fertility rates among treatments were not significant. However, the semen supplemented with $1 \%$ soy lecithin (L1) achieved a numerically higher percentage of fertilization in comparison to the control and 2\% (L2) groups. This finding followed the same trend as the results of all the evaluations performed in the present study.

While egg yolk is a main component in extenders for storage and cryopreservation of semen in most mammalian species, many literatures reported that the detrimental effects of egg yolk on sperm fertility. MullerSchlosser et al. (2001) observed that steroid hormones and its precursors present in egg yolk were associated with lower fertilization potential of stallion spermatozoa. In addition, Amirat et al. (2005) reported higher sperm numbers of bull with functionally intact acrosomes cryopreserved in soya lecithin-based extender as compared to an egg yolk-based extender and speculated that presence of higher calcium ions of egg yolk might be responsible for the acrosomal damage. Nevertheless, Papa et al. (2011) obtained lesser fertility rates of stallion semen using soybean lecithin diluents.

Previously, Lopez and Alvarino (1998) reported that the fertility of stored rabbit semen was ranged from 84.14 to $39.23 \%$ related to the conservation time of fresh semen from $2 \mathrm{~h}$ to $96 \mathrm{~h}$, respectively. When studying the period of 24 hours, the fertility obtained by them was similar to this work, located around 64\%. Decreased fertility with the using of cooled stored rabbit semen older than 24-48 h observed by Aksoy et al. (2008) and Iaffaldano et al. (2010) and it may be the consequence of deterioration in 
Table 3. Pregnancy rates, as a result of insemination with three different extenders.

\begin{tabular}{lcccc}
\hline \multirow{2}{*}{ Traits } & \multicolumn{3}{c}{ Semen extenders } & Total \\
\cline { 2 - 4 } & L0 & L1 & L2 & \\
\hline No. of Does inseminated & 34 & 34 & 30 & 98 \\
No. of Pregnant does & 20 & 21 & 18 & 59 \\
Pregnancy rate $(\%)$ & 58.82 & 61.76 & 60.00 & 60.20 \\
\hline
\end{tabular}

L0; Lecithin free extender, L1; $1 \%$ lecithin containing extender, L2; $2 \%$ lecithin containing extender

semen quality observed over storage time. This is consistent with researches showing a positive relationship between in vitro semen characteristics and in vivo reproductive performances of rabbits (Brun et al., 2002 and Lavara et al., 2005).

Conclusively, it could be concluded that soybean lecithin, as a lipoprotein source, can be used as an alternative to animal products in extenders preparation for preserving rabbit semen without any debris in fertility.

\section{REFERENCES}

Aires, V. A., K. D. Hinsch, F. Mueller-Schloesser, K. Bogner, S. MuellerScloesser and E. Hinsch, (2003). In vitro and in vivo comparison of egg yolk-based and soybean lecithin-based extenders for cryopreservation of bovine semen. Theriogenology 60:269-279.

Aksoy M., N. Cankat Lehimcio ğlu and O. Akman, (2008). Effect of seminal plasma on functional integrity of rabbit sperm membranes during storage at $4^{\circ} \mathrm{C}$ or freezing. World Rabbit Sci., 16:1-6.

Amirat L., M. Anton, D. Tainturier, G. R. Chatagnon, I. Battut and J. L. Courtens, (2005). Modifications of bull spermatozoa induced by three extenders: Biociphos, low density lipoprotein and Triladyl, before, during and after freezing and thawing. Reproduction , 129:535- 43.

Anel L., M. Alvarez, F. Martínez-Pastor, S. Gomes, M. Nicolas, M. Mata, A. F. Martínez, S. Borragan, E. Anel and P. de Paz, (2008). Sperm Cryopreservation in Brown Bear (Ursus arctos): Preliminary Aspects. Reprod. Dom. Anim. 43 Suppl 4: 9-17.

Anel L., M. Alvarez, F. Martínez-Pastor, V. García-Macías, E. Anel and P. de Paz, (2006). Improvement strategies in ovine artificial insemination. Reprod. Dom. Anim., 41 Suppl 2:30-42. 
Aurich, C. and J. Spergser, (2007). Influence of bacteria and gentamicin on cooled-stored stallion spermatozoa. Theriogenology. 67: 912-918

Bencharif D., L. Amirat, O. Pascal, M. Anton, E. Schmitt, S. Desherces, G. Delhomme, M. L. Langlois, P. Barrière, M. Larrat and D. Tainturier, (2008). The advantages of combining low-density lipoproteins with glutamine for cryopreservation of canine semen. Reprod. Dom. Anim. 45:189-200.

Brun J. M., M. Theau-Clement and G. Bolet, (2002). The relationship between rabbit semen characteristics and reproductive performance after artificial insemination. Animal Reproduction Science, 70: 139-149.

Bucak MN, Tekin N, (2007). Protective effect of taurine, glutathione and trehalose on the liquid storage of ram semen. Small Rumin Res 73, 103-108.

Corona, A. and R. Cherchi, (2009).Microbial quality of equine frozen semen. Animal Reproduction Science. 115:103-109.

Duncan, D. B., (1955). Multiple range and multiple F- test. Biometrics, 11:1- 42.

Farstad, W. (1996). Semen cryopreservation in dogs and foxes. Anim. Reprod., Sci., 42: 251-260.

Gil J., A. Januskauskas, M. Haard, M. G. M. Haard, A. Johanis, L. Söderquist and H. Rodriguez-Martinez, (2000). Functional sperm parameters and fertility of bovine semen extended in biociphos plus and triladyl. Reprod. Dom. Anim., 35:69-77.

Gil J., M. Rodriguez-Irazoqui, N. Lundeheim, L. Söderquist and H. Rodríguez-Martínez, (2003). Fertility of ram semen frozen in Bioexcell and used for cervical artificial insemination. Theriogenology. 59:1157-1170.

Houdebine, L.M. and J. Fun., (2009). Rabbit Biotechnology Rabbit Genomics, Transgenesis, Cloning and Models. Springer Dordrecht Heidelberg London New York. e-ISBN 978-90-481-2227-1.

Iaffaldano N., M. P. Rosato, G. Paventi, R. Pizzuto, M. Gambacorta, A. Manchisi and S.Passarella, (2010). The irradiation of rabbit sperm cells with $\mathrm{He}-\mathrm{Ne}$ laser prevents their in vitro liquid storage dependent damage. Animal Reproduction Science, 119: 123-129.

Kim S., Y.J. Lee, Y.J. Kim, (2011). Changes in sperm membrane and ROS following cryopreservation of liquid boar semen stored at $15^{\circ} \mathrm{C}$. Anim. Reprod. Sci 124, 118-124.

Kmenta I., C. Strohmayer, F. Müller-Schlösser and S. Schäfer-Somi, (2011). Effects of a lecithin and catalase containing semen extender and a second dilution with different enhancing buffers on the quality of cold-stored canine spermatozoa. Theriogenology, 75:1095-1103. 
Lavara R., E. Moce, F. Lavara, M. P. V. de Castro and J. S. Vicente, (2005). Do parameters of semen quality correlate with the results of onfarm inseminations in rabbits. Theriogenology, 64: 1130-1141.

Lopez F. J. and J. M. R. Alvarino, (1998). Artificial insemination of rabbits with diluted semen stored up to 96 hours. World Rabbit Sci., 6:251-253.

Mocé E. and J.S.Vicente, (2009). Rabbit sperm cryopreservation: a review. Anim. Reprod. Sci., 110:1-24

Morrell J. M., (1995). Artificial insemination in rabbit. British Vet. J., 151:477-488.

Muller-Schlosser, F., V. Aires, E. Hinsch and K. D. Hinsch, (2001). Evaluation of the quality of a new generation of egg yolk free semen diluters for cryopreservation of bovine semen. $34^{\text {th }}$ Jahrestagung Physiologie und Pathologie der Fortpflanzung, Giessen, pp. 54.

Pagl R., J. E. Aurich, F. Müller-Schlösser, M. Kankofer and C. Aurich, (2006). Comparison of an extender containing defined milk protein fractions with a skim milk-based extender for storage of equine semen at $5^{\circ} \mathrm{C}$. Theriogenology, 66:1115-1122.

Papa F. O., G. B. Felicio, C. M. Melo, M. A. Alvarenga, B. De Vita, B. R. Avanzi and J. A. Dell'Aqua, (2010). Effect of substituting soybean lecithin for egg yolk in an extender used for the cryopreservation of stallion semen. Animal Reproduction Science, 121:71-72.

Papa F. O., G. B. Felicio, C. M. Melo, M. A. Alvarenga, B. De Vita, C. Trinque, J. N. P. Puoli-Filho and J. A. Dell'Aqua, (2011). Replacing egg yolk with soybean lecithin in the cryopreservation of stallion semen. Animal Reproduction Science, 129:73-77

Phutikanit, N., E. Sangkrachang, J. Suwimonteerabutr, J. Singlor, (2011). Effect of sources and concentrations of soybean phosphatidylcholine on diluted goat semen equilibrated at $4^{\circ} \mathrm{C}$. J. Agric. Sci. Tech., A 1: 1170-1173.

Quintela L. A., A. I. Pena, M. D. Vega, J. Gullon, C. Prieto, M. Barrio, J. J. Becerra, F. Maseda and P. G. Herradon, (2004). Ovulation induction in rabbit does submitted to artificial insemination by adding buserelin to the seminal dose. Reprod. Nutr. Dev., 44: 79-88.

Ricker J. V., J. J. Linfor, W. J. Delfino, P. Kysar, E. L. Scholtz, F. Tablin, J. H. Crowe, B. A. Ball and S. A. Meyers, (2006). Equine sperm membrane phase behavior: the effects of lipid-based cryoprotectants. Biol. Reprod., 74: 359-365.

Roca J, S. Martínez, J.M. Vázquez, X. Lucas, I. Parrilla, E.A. Martínez, (2000). Viability and fertility of rabbit spermatozoa diluted in Tris buffer extenders and stored at 15 degrees C. Animal Reprod. Sci., 64: 103-12. 
Salmani H., M.M. Nabi, H. Vaseghi-Dodaran, M.B. Rahman, A. MohammadiSangcheshmeh, M. Shakeri, A. Towhidi, A.Z. Shahneh, M. Zhandi, (2013). Effect of glutathione in soybean lecithinbased semen extender on goat semen quality after freeze-thawing. Small Rum. Res., 112: 123-127.

SAS, (2004): Statistical Analysis System. Users Guide, Statistics. SAS Institute Inc., Cary, North Carolina, USA.

Thun A., M. Hurtado and F. Janett, (2002). Comparison of biociphos-plus $\mathrm{R}$ and tris-egg yolk extender for cryopreservation of bull semen. Theriogenology, 57:1087-1094.

Van Wagtendonk-de Leeuw A. M., R. M. Haring, L. M. KaalLansbergen and J. H. den Daas, (2000). Fertility results using bovine semen cryopreserved with extenders based on egg yolk and soybean extract. Theriogenology, 54: 57-67.

Vidal, A.H., A.M. Batista, E.C. Bento da Silva, W.A. Gomes, M.A. Pel inca, S.V. Silva, M.M.P. Guerra, (2013). Soybean lecithin-based extender as an alternative for goat sperm cryopreservation. Small Rum. Res., 109:47-51.

Yotov S., (2015). Effect of TFC-based extenders with soybean lecithin and/or low concentration of glycerol on the quality of goat chilled-stored semen. Int. J. Curr. Microbiol. App. Sci. 4 (3): 752-761

Zhang, S.S., J.H. Hu, Q.W. Li, Z.L. Jiang, X.Y. Zhang, (2009). The cryoprotective effects of soybean lecithin on boar spermatozoa quality. Afr. J. Biotechnol. 8: 6476-6480.

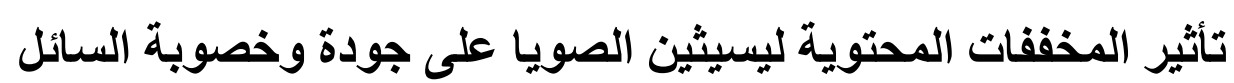

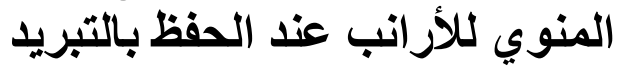

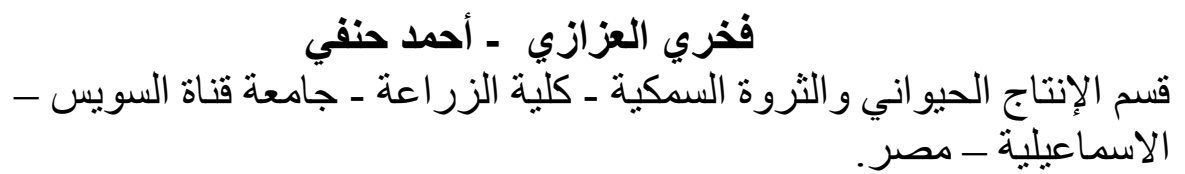

استهدفت هذه الدراسة تقييم أثر استخدام لبسيثين فول الصويا بدلاً من صفار

البيض في المخففات على جودة وخصوبة السائل المنوي للأر انب عند الند حفظة بالتبريد

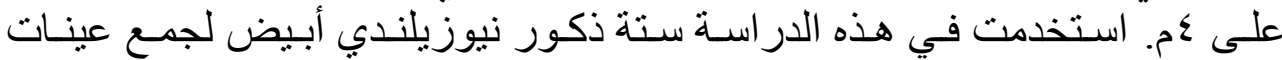

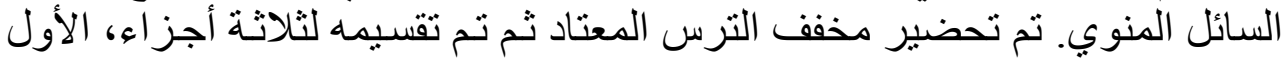

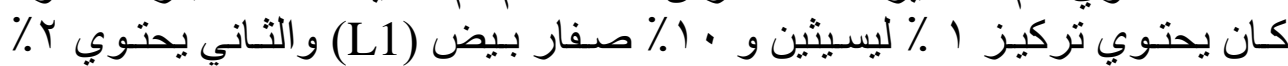


ليسيثين دون صفار بيض (L2) و الثالث يحتوي 0 (L) صفار بيض فقط و لا يحتوي

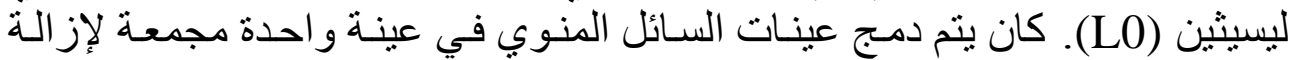

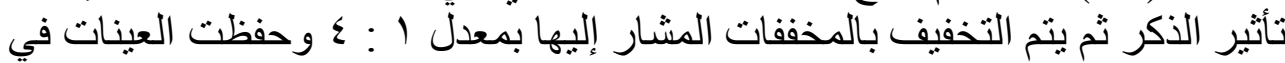

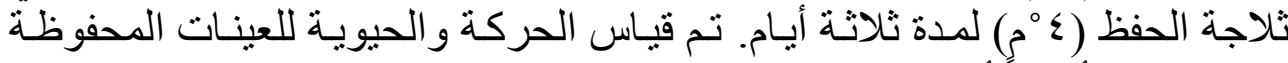

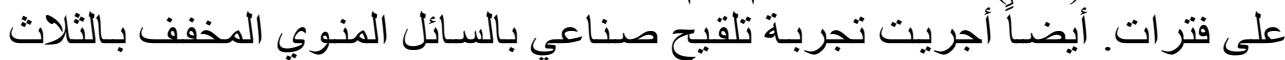

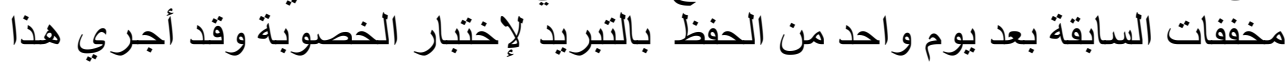

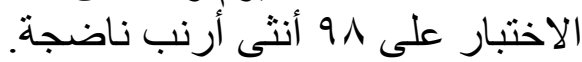

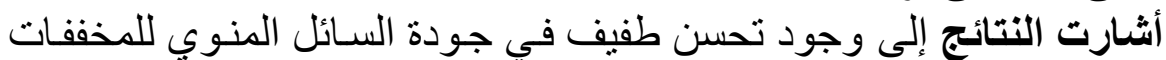

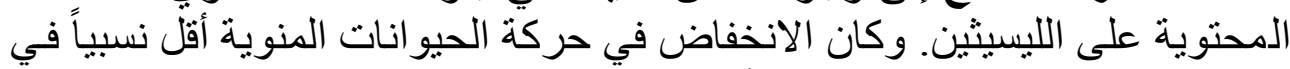

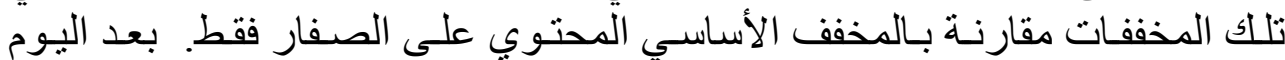

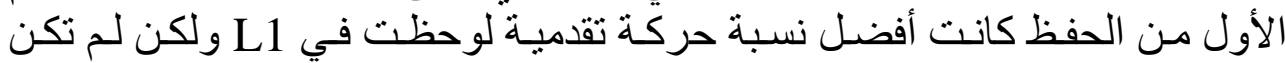

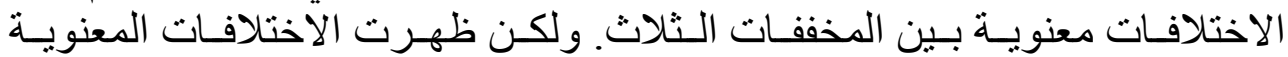

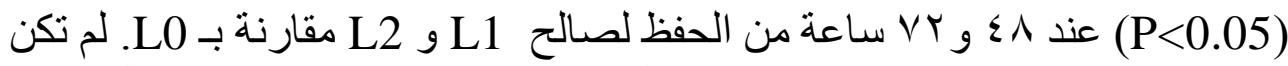

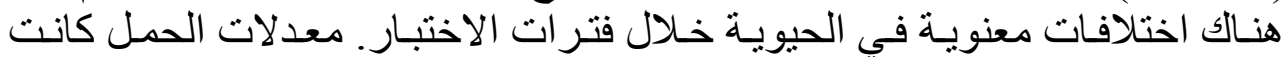

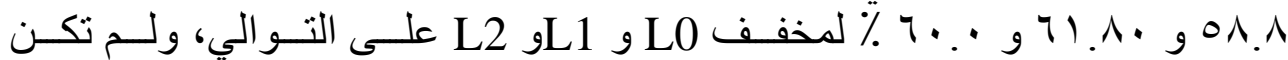
الاختلافات بينها معنوية.

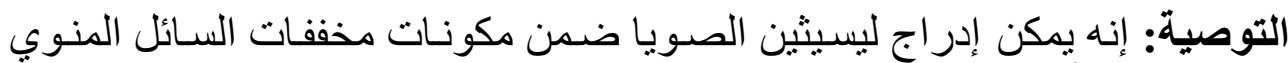

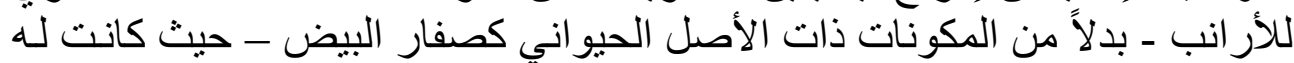

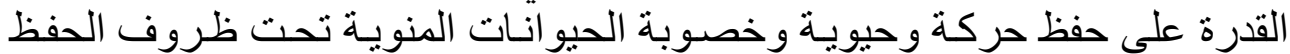
بالتبريد. 